\title{
Expectations of orthodontic treatment in adults: The conduct in orthodontist/patient relationship
}

\author{
Ricardo Alves de Souzaํ, André Frutuoso de Oliveira², Suélem Maria Santana Pinheiro ${ }^{3}$, Jefferson Paixão Cardoso ${ }^{4}$ \\ Maria Beatriz Borges de Araújo Magnani
}

Introduction: The high demand for orthodontic treatment, evidenced over the last few decades, has been justified mainly by the greater importance given to facial esthetics, influencing individual's self esteem. However, the professional frequently does not meet all the patient's expectations, for not establishing good communication and not knowing about the critical points during orthodontic treatment. Objective: The aim of this study was to elucidate patients' desires and doubts regarding orthodontic treatment, by means of a survey applied to 60 adult patients. Results: The analysis of results revealed that most individuals (38.3\%) noticed treatment success after its conclusion. Occlusion deviation was pointed out by $66.7 \%$ as the main reason for seeking treatment, and esthetics ranked as second (with 48.3 $\%)$. Treatment time was considered within the prediction by $46.7 \%$ of the interviewees and the results were judged as very good by $43.3 \%$. The social relations of most participants were not affected by treatment $(73.3 \%)$. Also, $58.3 \%$ of the interviewees reported pain as the main complaint and $53.3 \%$ found it difficult to use dental floss. Most participants saw the orthodontist as a professional who was concerned about their health $(76.7 \%)$, and believed that he/she was more able to treat them (96.6\%) when compared with the general practitioner. Conclusion: The orthodontist/ patient relationship enables an understanding of the expectations regarding orthodontic treatment, resulting in greater motivation and cooperation, leading to a successful outcome.

Keywords: Orthodontics. Adults. Facial pain. Malocclusion. Dental esthetics.

Introdução: a elevada procura por tratamentos ortodônticos, evidenciada nas últimas décadas, justifica-se principalmente pela maior importância à estética facial, influenciando a autoestima do indivíduo. Entretanto, muitas vezes o profissional não atinge todas as expectativas esperadas pelo paciente, por não estabelecer uma correta comunicação e conhecer os pontos críticos durante o tratamento ortodôntico. Objetivo: esse estudo objetivou elucidar os anseios e dúvidas de pacientes em relação ao tratamento ortodôntico por meio da aplicação de questionário a 60 pacientes adultos. Resultados: a análise dos resultados revelou que a maioria dos indivíduos $(38,3 \%)$ percebeu êxito após a finalização da terapêutica. O desvio da oclusão foi apontado por $66,7 \%$ como principal motivo de procura pelo tratamento, e, em segundo lugar, 48,3\% pela estética. O tempo de tratamento foi considerado dentro do previsto por 46,7\% dos entrevistados e os resultados foram julgados como muito bons para 43,3\%. As relações sociais da maioria dos participantes não foram afetadas pelo tratamento $(73,3 \%)$, sendo que $58,3 \%$ dos entrevistados relataram a dor como queixa principal, e $53,3 \%$ encontraram dificuldades no uso do fio dental. A maioria dos participantes vê o ortodontista como um profissional preocupado com sua saúde (76,7\%), e acredita que é mais apto em relação ao clínico-geral para tratá-los (96,6\%). Conclusão: o vínculo entre profissional e paciente possibilita compreender as expectativas em relação ao tratamento ortodôntico, resultando em maior motivação, cooperação e sucesso do tratamento.

Palavras-chave: Ortodontia. Adultos. Dor facial. Má oclusão. Estética dentária.

\footnotetext{
${ }^{1} \mathrm{MSc}$ and Specialist in Orthodontics, UNICAMP. Assistant Professor of Orthodontics, UESB.

${ }^{2}$ Graduated in Dentistry, UESB.

${ }^{3} \mathrm{MSc}$ in Social Health, UEFS. Professor, Dental Practice in Social Health, FAINOR.

${ }^{4}$ Professor, Social Health, UESB.

${ }^{5} \mathrm{PhD}$ and MSc in Orthodontics, UNICAMP. Assistant Professor of

Orthodontics, UNICAMP.
}

» The author reports no commercial, proprietary or financial interest in the products or companies described in this article.
How to cite this article: Souza RA, Oliveira AF, Pinheiro SMS, Cardoso JP, Magnani MBBA. Expectations of orthodontic treatment in adults: The conduct in orthodontist/patient relationship. Dental Press J Orthod. 2013 MarApr;18(2):88-94.

Submitted: March 29, 2009 - Revised and accepted: April 12, 2010

Contact address: Ricardo Alves de Souza

Rua José Moreira Sobrinho, S/N - Jequiezinho - Jequié/BA - Brazil

CEP: 45.200-000 - Email: ricardoalves@ortodontista.com.br 


\section{INTRODUCTION}

The mouth represents the man's first organ of relation with the environment, enabling nutrition, the establishment of social relations through speech, and cognitive development of the individual. It is also a striking feature for individualization of human being, besides presenting esthetic value and mediating interpersonal events. ${ }^{29}$ The face also represents a key element in personal attractiveness and development of self-esteem. Within the wide concept of health, which covers the psychosocial well-being, facial appearance may interfere in various areas of social relations, since facial deformities with negative social and psychological reflexes act on patients' self-confidence, perception of beauty, about external relations, and even on identification with professional success. ${ }^{13}$ Besides, the difficulty in quantifying the welfare and incapability to conceptualize it in human societies generally involves the use of impregnated concepts of subjectivity. ${ }^{15}$

In recent decades, a high demand for orthodontic treatment in adults was observed. ${ }^{3}$ This fact is due to the increased awareness by patients of the need for good oral health, enabling the patient to reach adulthood with a greater number of teeth in the mouth. ${ }^{3}$ It also happens by the increase on esthetic requirement from society. $3,7,8,13,16$ by the increased access to information for the public about orthodontic treatment, and by the technological advancements in the field of orthodontics. ${ }^{3}$ However, some "dogmas" regarding orthodontic treatment such as lack of communication between the parties involved, expectations for different results from patient in relation to the professional's view and technical glitches persist among the population in general, resulting in failure or dissatisfaction with treatment.

Despite these functional problems being always expressed by changes in chewing, orofacial pain, disproportions of the facial skeleton, it is the esthetic complaints, in most cases, that stimulate these patients to seek orthodontic treatment. The relative importance of esthetics in current society is understood when analyzing the positive attributes associated with physical attractiveness. ${ }^{1}$

Four factors are considered important for the success or failure of orthodontic treatment in adults: (1) Motivation, the patient must first be interested and aware of their appearance. (2) Mobility; teeth may have progressive mobility and continuous migrations. (3) Limitations; health of the oral tissues must be good and at least three quarters of the teeth's roots should be surrounded by alveolar bone, and no evident root resorption. (4) Cooperation, the patient should follow the guidelines for use of removable and fixed appliances, maintaining a long period of retention, and the use of fixed prosthesis as permanent retention. ${ }^{23}$

Many adults did not have the opportunity to take an orthodontic treatment at a young age due to lack of information or lack of financial resources. However, the top reasons for treatment in adults are: Increased cooperation, caring for the device, maintaining better oral hygiene and compliance with the guidelines. ${ }^{6}$ A direct approach should be used in adults to eliminate the patient's complaint, limited to regions of the dental arch with some esthetic and functional impairment. ${ }^{3}$

A comparison of patients' self-esteem in orthodontic treatment with the general population did not show variations, however facial and occlusal self-perception is higher in orthodontic patients than general population, which demonstrates a decreased facial and body self-image. Most of the time the orthodontic treatment in adults results in improved self-image, which justifies its performance, even for purely esthetic reasons. ${ }^{28}$

Knowing patients expectations regarding treatment in order to adapt them to the real therapeutic possibilities, considerably increases the chances of satisfaction with the final results. Besides, encouraging the participation of the patients in choosing the best treatment alternative will necessarily make them think better about their real intentions in treatment, making them co-responsible, and this will reflect positively on the professional-patient relation. ${ }^{13}$ Otherwise, there might be dissatisfaction with the orthodontic therapy. ${ }^{17}$

Since some dental characteristics are more noticed than others, the patient's perception of their own problem may differ from the professional's perception of it, being essential for general dentists to engage in a dialogue with their patients before carrying out any intervention, ensuring a safer approach on the patient's complaints and more satisfactory results for both of them. ${ }^{20}$ 
When analyzing the goals for orthodontic treatment among patients in general, it was found that both those undergoing therapy and others described their dentitions, and $82 \%$ of those orthodontically treated immediately identified the photograph of their teeth. It is evident that young adults have a great awareness about their own occlusion, independent of orthodontic treatment, inferring to these patients the appreciation of a good therapy result and significance of professional goals. ${ }^{5}$

Therefore, it becomes essential to have a deeper understanding about the possible effects that the use of orthodontic appliances can cause in psychosocial relations of orthodontic patients in order to improve the results of orthodontic treatment, becoming the main objective of this study.

\section{MATERIAL AND METHODS}

A cross-sectional study was conducted in 2008 to assess expectations of adult patients in relation to orthodontic treatment, as well as to the responsible professional. The sample consisted of 60 students from the Southwest Bahia State University (UESB) randomly assigned. The inclusion criteria were students presenting ages between 18 and 25 years and had already undergone orthodontic treatment with fixed appliances or were in the final stages of treatment. Volunteers who did not properly complete the survey were excluded, leaving it incomplete or damaged, those who presented less than 1 year of treatment, and those in which treatment started before 18 years of age. In order to standardize the data, the period between the completion or abandonment of orthodontic treatment, and the time when the survey was applied in this study could not surpass three years.

The instrument of data collection was a survey composed of 10 closed-ended questions, drawn from a pilot study conducted at Southwest Bahia State University, in 2004. This pilot demonstrated the feasibility of this instrument, adjusting the questions according to data obtained in orthodontic literature for studies of this nature. The survey was conducted by a single researcher, impartial and committed to not interfere with spontaneous answers provided by volunteers within the period from January to December 2008.

The survey was formulated to include demographic aspects (gender and age), patient expecta- tions in relation to orthodontic treatment and patient expectations in relation to the professional. So, after quantifying the data, the purpose was to determine the behavior, during planning and performance, that provided the qualitative deficiencies of orthodontic treatment.

The data were tabulated in a spreadsheet and analyzed using the statistical package Statistical Package for Social Sciences - SPSS, version 9.0. Calculating the gross and relative frequency provided the characterization of the studied population. To assess differences in proportion a binomial test was used on "main reason for seeking orthodontic treatment" according to sex, with a confidence interval of $95 \%$.

This study was approved by the Research Ethics Committee (REC) of the Southwest Bahia State University (UESB) under the protocol number 010/2008.

\section{RESULTS}

The studied sample consisted of 60 individuals, and there was predominance of women (74.1\%). Most (53.2\%) were between 18 and 21 years of age (Table 1).

According to the situation of orthodontic therapy, $38.3 \%$ of the sample noticed that the treatment was successful. In this therapy, the type of orthodontic appliance used in most cases $(96.4 \%)$ was fixed metal brackets. The main reason behind the search for orthodontic treatment was reported by $66.7 \%$ as the deviations in the occlusion (Table 2).

The main reasons that led to search for orthodontic treatment segregated by sex with respective percentages are shown in Table 3.

Regarding the duration of orthodontic treatment, $46.7 \%$ of the participants considered it on schedule.

\begin{tabular}{|c|c|c|}
\hline Variables & $n=58$ & $\%$ \\
\hline \multicolumn{3}{|l|}{ Gender } \\
\hline Female & 43 & 74.1 \\
\hline Male & 15 & 25.9 \\
\hline \multicolumn{3}{|l|}{ Age } \\
\hline 18 to 21 years & 33 & 53.2 \\
\hline 21 to 25 years & 27 & 46.8 \\
\hline
\end{tabular}


Table 2 - Patient expectations in relation to the orthodontic treatment.

\begin{tabular}{|c|c|c|}
\hline Variables & $n=60$ & $\%$ \\
\hline \multicolumn{3}{|l|}{ Orthodontic treatment situation } \\
\hline Finished successfully & 23 & 38.3 \\
\hline Finished unsuccessfully & 6 & 10.0 \\
\hline In treatment, presenting improvement & 20 & 33.3 \\
\hline In treatment, with no improvement & 4 & 6.7 \\
\hline Not concluded & 7 & 11.7 \\
\hline \multicolumn{3}{|l|}{ Main reason for searching orthodontic treatment } \\
\hline Esthetics & 29 & 48.3 \\
\hline Occlusal disturbances & 40 & 66.7 \\
\hline TMJ pain & 2 & 3.3 \\
\hline \multicolumn{3}{|l|}{ Treatment duration } \\
\hline Quick & 1 & 1.6 \\
\hline As expected & 28 & 46.7 \\
\hline Long due to case complexity & 16 & 26.7 \\
\hline Long due to lack of cooperation & 15 & 25.0 \\
\hline \multicolumn{3}{|l|}{ Treatment results } \\
\hline Very good. Esthetic, social and psychological improvement & 26 & 43.3 \\
\hline Satisfactory, but did not change social and psychological life & 24 & 40.0 \\
\hline Regular & 4 & 6.7 \\
\hline Bad. Did not fulfill expectations & 1 & 1.7 \\
\hline Bad. The problem relapsed & 5 & 8.3 \\
\hline \multicolumn{3}{|l|}{ Type of orthodontic appliance* } \\
\hline Metallic & 54 & 96.4 \\
\hline Removable transparent & 2 & 3.6 \\
\hline \multicolumn{3}{|l|}{ Interference of orthodontic treatment in social relations } \\
\hline Partial, compromising smile and relations & 2 & 3.3 \\
\hline Partial, without compromising social life & 14 & 23.3 \\
\hline Did not interfere & 44 & 73.3 \\
\hline \multicolumn{3}{|l|}{ Interference of orthodontic treatment in oral hygiene } \\
\hline No difficulties in oral hygiene & 18 & 30 \\
\hline Difficulties only in flossing & 32 & 53.3 \\
\hline Difficulties in brushing and flossing & 10 & 16.7 \\
\hline \multicolumn{3}{|l|}{ Main complaint about treatment } \\
\hline Duration & 19 & 31.7 \\
\hline Pain & 35 & 58.3 \\
\hline Oral hygiene & 13 & 21.7 \\
\hline Esthetics & 1 & 1.7 \\
\hline Difficulty in chewing & 14 & 23.3 \\
\hline Difficulty in using orthodontic auxiliaries & 5 & 8.3 \\
\hline High financial cost & 16 & 26.7 \\
\hline
\end{tabular}

${ }^{*} n=56$.

Table 3 - Main reason that led patient to perform orthodontic treatment.

\begin{tabular}{ccccccc}
\hline Variable & \multicolumn{2}{c}{ Female } & \multicolumn{3}{c}{ Male } & p-value* \\
& $n$ & $\%$ & $n$ & $\%$ & \\
\hline Esthetics & 26 & 90 & 3 & 10 & $<0.001$ \\
\hline Occlusal disturbances & 15 & 75 & 5 & 25 & 0.41 \\
\hline TMJ pain & 42 & 75 & 14 & 25 & $<0.001$ \\
\hline
\end{tabular}

* Z test.
Table 4 - Patient expectations in relation to the orthodontist

\begin{tabular}{lll}
\hline Variables & $\mathbf{n = 6 0}$ & $\%$ \\
\hline Patients opinion in relation to the orthodontist & & \\
\hline Concerned with patient's health & 46 & 76.7 \\
\hline Concerned with patient's health, but unprepared & 3 & 5.0 \\
\hline Concerned with patient's health, but with no skills & 5 & 8.3 \\
\hline Little concern with patient & 6 & 10.0 \\
Profiessional which should perform the orthodontic treatment \\
\hline General practitioner & 2 & 3.4 \\
\hline Specialist & 58 & 96.6 \\
\hline
\end{tabular}

The results obtained with treatment were considered very positive by $43.3 \%$. As for the interference of the use of orthodontic appliance in social relations, $73.3 \%$ of the sample rated that no kind of commitment to social life occurred. On the issue of oral hygiene, $53.3 \%$ of the sample had difficulties to floss, and most $(58.3 \%)$ reported pain or discomfort as chief complaint resulting from treatment (Table 2).

As for the expectations of the volunteers in relation to the orthodontist, $76.7 \%$ see the orthodontist as a professional concerned about the patient's health and $96.6 \%$ felt that orthodontic therapy should be performed by a specialist in orthodontics (Table 4)

\section{DISCUSSION}

In the present study we found a prevalence of females, expressed in a 3:1 relation, relative to demand for orthodontic treatment. This suggests a greater tendency of women seeking orthodontic treatment, corroborating with the studies by other authors. ${ }^{13,24,26,27}$ This proportion shows that women are more demanding about esthetics and appearance, and more uninhibited in expressing their dissatisfaction about themselves. ${ }^{24}$

Most participants (38.3\%), when asked about the situation of fixed orthodontic treatment, judged that it was successful. More important than the disfigurement due to malocclusion is the psychosocial impact and response caused by it, to determine the need for treatment and evaluation of the success of orthodontic therapy. ${ }^{29}$ In an orthodontic approach it is fundamental to know the esthetic and functional complaints that lead the patient to seek treatment enabling a greater approach between the practitioners treatment and the patient's desires and concerns. 
Thus, greater collaboration is expected from the patient regarding orthodontic treatment and satisfaction with the results achieved.

The main factor that motivated the participants to seek orthodontic treatment was the occlusion deviation expressed by $66.7 \%$ of subjects, this result corroborates those described in other studies, which emphasized as most frequent reason the presence of problems on biting and chewing. ${ }^{10,18}$ The concern with dentofacial health is influenced by the individuals' sociocultural conditions. ${ }^{25}$ The fact that the study sample is composed of individuals with high level of education suggests an influence of the expression of occlusal deviation as the main reason for treatment, since they can better recognize the impact of a malocclusion on their health.

Other studies are opposite to this reality when dentofacial esthetics is pointed as the primary cause in seeking orthodontic treatment without, however, excluding the functional reasons as prevalent in the decision for treatment. ${ }^{7,8,1}$ Better social and work opportunities are crucial for esthetics to appear as the main factor in the demand for orthodontic intervention..$^{29}$ In this study, the esthetic factor was reported by $48.3 \%$ of individuals as one of the most prevalent reasons for submission to orthodontic treatment.

Comparatively in the case of females in this study, the main reason for seeking orthodontic treatment was the esthetic factor $(p<0.001)$, emphasizing the idea that women have a greater concern with appearance and facial attractiveness and greater willingness to assume such fact. While for men the main reason cited was pain in Temporomandibular Joint (TMJ), within the established significance level ( $p<0.001)$.

For most participants $(46.7 \%)$ there was a perception that treatment duration occurred within the predicted time. Orthodontic therapy is an intervention that requires, in most cases, a long period of time for its completion. In this sense, explaining to the patient this possibility, even before treatment is initiated, it is essential so that there is no mismatch between the time required to finish orthodontic treatment and patient's expectations. The long treatment period is also mainly associated to the non-attendance to orthodontic consultations for appliance activation. ${ }^{2}$ Thus, it is important that the professional explains and motivates the patients regarding their responsibility for their own treatment. In this study, $25 \%$ of participants said that the treatment time was prolonged because of missed scheduled appointments.

When asked about the perception of treatment progress or outcome, most participants (43.3\%) reported as very good, reporting esthetical, social, and psychological improvement. Based on this data, it was verified that the goals of orthodontic treatment were achieved, in the mentioned areas, contributing to improve the patient's facial esthetics and thereby raising their self-esteem and promoting their social relations. People from lower middle class considered orthodontic treatment more important than the upper middle class, because they believe that it represents an opportunity for better acceptance and social integration, enabling higher aspirations. ${ }^{29}$

For most individuals (96.4\%), orthodontic treatment was performed with fixed appliances, which is expected, considering the studied age.

Most individuals in this study (73.3\%) said that the fact of using fixed appliances did not interfere in their socio-affective relations. However, in a study that examined the factors that contribute to the acceptance of fixed appliances, an aversion in using it in public was found, but this reduces gradually with time and with the increased expectation of a good result. ${ }^{4}$ As most volunteers had completed or were in the final stage of treatment, it is evident that the values found agree to what was previously mentioned, because most of them were satisfied with the results achieved with orthodontic treatment. The detailed explanation about the importance of completing treatment, emphasizing oral health and facial esthetics can facilitate the initial rejection to fixed appliances. The use of fixed appliances did not affect self-esteem during treatment and an improvement in self-image was observed, justifying the completion of treatment. ${ }^{14,28}$

Regarding oral hygiene during orthodontic treatment, most individuals (53.3\%) reported difficulties in flossing. Failure of appropriate oral hygiene during orthodontic treatment may compromise treatment completion, since the risk of tissue damage, as demineralization of teeth and periodontal inflammation, may require premature discontinuation of therapy. ${ }^{21}$ The components of the orthodontic appliance create additional retention sites for oral biofilm and at the same time hinder oral cavity hygiene. 
It is evident the difficulty in removing biofilm during orthodontic treatment mainly in the cervical region of teeth with orthodontic bands and interproximal regions with brackets. ${ }^{19}$

Thus, orthodontic treatment should aim both to correct patient's occlusion and to maintain the preexisting health of the teeth and supporting tissues. The individualization of preventive models is a decision to be made, considering the characteristics of each patient according to the risk of caries and periodontal disease, and even their level of cooperation. ${ }^{9}$

The main complaint of orthodontic treatment was pain, reported by $58.3 \%$ of participants. The pressures exerted by the fixed appliances on the periodontal ligament associated with increased friction of the brackets on the mucosa are the main sources of painful symptoms related to orthodontic therapy. ${ }^{12}$ Other studies related the complaints arising from orthodontic therapy and showed that ulcers were the most annoying treatment factor, cited by $47 \%$ of respondents, followed by the discomfort caused by appliance activation, with $38 \%$ of complaints. ${ }^{11}$ Orthodontics still has few resources for the adequate management of these complications.

The image of orthodontists from most of the participants $(76.7 \%)$ was a professional committed to the restoration of their health. A good dentist values the interpersonal relationship, based on communication, seeking ways to preserve or restore oral health and showing kindness to patients, to their complaints and concerns. ${ }^{22}$

Most participants (96.6\%) stated that orthodontic treatment should be performed by a specialist in orthodontics. Due to the technical complexity required to perform a treatment of this nature, plus the little knowledge in orthodontics offered in undergraduate courses of dentistry, it is evident the need for greater differentiation of the general dentist to practice the specialty. Patients judge the visits to the orthodontist much more pleasant than the general practitioner. ${ }^{29}$ This may be a result of increased security and expertise transmitted to the patient during treatment, when performed by professionals who are experts in this area.

\section{CONCLUSION}

"Most participants in this study believed that their orthodontic treatment was successfully completed within the predicted time, resulting in esthetical, social, and psychological improvement.

" The main reason for seeking orthodontic therapy in this study is occlusion deviation, and in dichotomization for genders, esthetics appears as the main factor among women, and TMJ pain for men.

» For most participants fixed appliances do not interfere in their social-affective relations, but brings some degree of flossing difficulty regarding oral hygiene.

" The main complaint about the treatment reported by participants refers to pain and discomfort.

" Most individuals see the orthodontist as a professional concerned about the patient's health and think that orthodontic treatment should be performed by specialists.

"It is essential that the orthodontist establish an effective communication with patients to understand their desires in relation to orthodontic treatment, achieving a higher level of trust, cooperation and finally, the success of the instituted therapy. 
1. Ambrizzi DR, Franz SA, Pereira Filho VA, Gabrielli MAC, Gimenez CM, Bertoz FA. Avaliação das queixas estético-funcionais em pacientes portadores de deformidades dentofaciais. Rev Dental Press Ortod Ortop Facial. 2007:12(5):63-70

2. Beckwith FR, Ackerman RJ Jr, Cobb CM, Tira DE. An evaluation of factors affecting duration of orthodontic treatment. Am J Orthod Dentofacial Orthop. 1999;115(4):439-47

3. Capelloza-Filho L, Reis S, Cavassan AO, Ozawa TO. Tratamento ortodôntico em adultos: uma abordagem direcionada. Rev Dental Press Ortod Ortop Facial. 2001; 6(5):63-80.

4. Doll GM, Zentner A, Klages U, Sergl HG. Relationship between patient discomfort, appliance acceptance and compliance in orthodontic therapy. J Orofac Orthop. 2000;61(6):398-413

5. Espeland LV, Stenvik A. Orthodontically treated young adults: awareness of their own dental arrangement. Eur J Orthod. 1991;13(1):7-14

6. Fastlicht L. Adult orthodontics. J Clin Orthod. 1982;16(9):606-18.

7. Gosney MBE. An investigation some of the factors influencing the desire for orthodontic treatment. Br J Orthod. 1986:13(2):87-94.

8. Hamdan AM. The relationship between patient, parent and clinician perceived need and normative orthodontic treatment need. Eur J Orthod. 2004:26(3):265-71

9. Heintze SD. A profilaxia individual em pacientes com aparelhos fixos recomendações para o consultório. Ortodontia. 1996:29(2):4-15.

10. Hoppenreijs TJ, Hakman EC, van't Hof MA, Stoelinga PJ, Tuinzing DB, Freihofer HP. Psychologic implications of surgical-orthodontic treatment in patients with anterior open bite. Int J Adult Orthodon Orthognath Surg. 1999:14(2):101-12.

11. Kvam E, Bondevik O, Gjerdet NR. Traumatic ulcers and pain in adults during orthodontic treatment. Community Dent Oral Epidemiol. 1989:17(3):154-7

12. Lima AAS, Grégio AMT, Tanaka O, Machado MÂN, Franca BHS Tratamento das ulcerações traumáticas bucais causadas por aparelhos ortodônticos. Rev Dental Press Ortod Ortop Facial. 2005;10(5):30-6.

13. Maltagliati LA, Montes LAP. Análise dos fatores que motivam os pacientes adultos a buscarem o tratamento ortodôntico. Rev Dental Press Ortod Ortop Facial. 2007:12(6):54-60

14. Mandall NA, Matthew S, Fox D, Wright J, Conboy FM, O'Brien KD Prediction of compliance completion of orthodontic treatment: are quality of life measures important? Eur J Orthod. 2008;30(1):40-5.

15. Nascimento Sobrinho CL. Organização, gestão e financiamento dos serviços de saúde. Textos Didáticos de Saúde e Comunidade, Feira de Santana; 1997
16. Nattrass C. Sandy JR. Adult orthodontics: a review. Br J Orthod. 1995:22:331-7.

17. Nicodemo D, Pereira MD, Ferreira LM. Cirurgia ortognática: abordagem psicossocial em pacientes Classe III de Angle submetidos à correção cirúrgica da deformidade dentofacial. Rev Dental Press Ortod Ortop Facial. 2007:12(5):46-54

18. Nurminen L, Pietilä T, Vinkka-Puhakka H. Motivation for and satisfaction with orthodontic-surgical treatment: a retrospective study of 28 patients. Eur J Orthod. 1999:21(1):79-87

19. Olympio KPK, Bardal PAP, Henriques JFC, Bastos JRM. Prevenção da cárie dentária e doença periodontal em Ortodontia: uma necessidade imprescindivel. Rev Dental Press Ortod Ortop Facial. 2006;11(2):110-9.

20. Pinheiro FHSL, Beltrão RTS, Freitas MR, Lauris JRP, Henriques JFC. Comparação da percepção e necessidade estética de tratamento ortodôntico entre pacientes e ortodontistas nas cidades de Natal/RN e João Pessoa/PB. Rev Dental Press Ortod Ortop Facial. 2005;10(2):54-61.

21. Richter DD, Nanda RS, Sinha PK, Smith DW, Currier GF. Effect of behavior modification on patient compliance in orthodontics. Angle Orthod. 1998:68(2):123-32

22. Robles ACC, Grosseman S, Bosco VL. Satisfação com o atendimento odontológico: estudo qualitativo com mães de crianças atendidas na Universidade Federal de Santa Catarina. Ciênc Saúde Colet. 2008:13(1):43-9

23. Seide LJ. Adult orthodontics. J Pro Dent. 1970;24(1):83.

24. Sergl GH, Zentner A. Study of psychosocial aspects of adult orthodontic treatment. Int J Adult Orthodon Orthognath Surg. 1997:12(1):17-22.

25. Stenvik A, Espeland L, Berset GP, Eriksen HM. Attitudes to malocclusion among 18 and 35 years old Norwegians. Community Dent Oral Epidemiol. 1996:24(6):390-3.

26. Tung AW, Kiyak HA. Psychological influences on the timing of orthodontic treatment. Am J Orthod Dentofacial Orthop. 1998:113(1):29-39.

27. Tuominen ML, Tuominen RJ, Nyström ME. Subjective orthodontic treatment need and perceived dental appearance among young Finnish adults with or without previous orthodontic treatment. Community Dent Health. 1994;11(1):29-33.

28. Varela M, García-Camba JE. Impact of orthodontics on the psychologic profile of adult patients: a prospective study. Am J Orthod Dentofacial Orthop. 1995:108(2):142-8

29. Vellini-Ferreira F, Monteiro EB. Aspectos psicológicos do tratamento ortodôntico. Rev Fac Odont. 1989:1(1):21-8 